\title{
Firing Modes of Dopamine Neurons Drive Bidirectional GIRK Channel Plasticity
}

\author{
Arnaud L. Lalive, ${ }^{1}$ Michaelanne B. Munoz, ${ }^{2}$ Camilla Bellone, ${ }^{1}$ Paul A. Slesinger, ${ }^{2,3}$ Christian Lüscher, ${ }^{1,4}$ and Kelly R. Tan ${ }^{1}$ \\ ${ }^{1}$ Department of Basis Neurosciences, Medical Faculty, University of Geneva, CH-1211 Geneva, Switzerland, ${ }^{2}$ Peptide Biology Laboratories, Salk Institute for \\ Biological Studies, La Jolla, California 92037, ${ }^{3}$ Department of Neuroscience, Icahn School of Medicine at Mount Sinai, New York, New York 10029, and \\ ${ }^{4}$ Department of Clinical Neurosciences, Clinic of Neurology, Geneva University Hospital, CH-1211 Geneva, Switzerland
}

G-protein-coupled inwardly rectifying potassium (GIRK) channels contribute to the resting membrane potential of many neurons, including dopamine (DA) neurons in the ventral tegmental area (VTA). VTA DA neurons are bistable, firing in two modes: one characterized by bursts of action potentials, the other by tonic firing at a lower frequency. Here we provide evidence that these firing modes drive bidirectional plasticity of GIRK channel-mediated currents. In acute midbrain slices of mice, we observed that in vitro burst activation of VTA DA neurons potentiated GIRK currents whereas tonic firing depressed these currents. This plasticity was not specific to the metabotropic receptor activating the GIRK channels, as direct activation of GIRK channels by nonhydrolyzable GTP also potentiated the currents. The plasticity of GIRK currents required NMDA receptor and CaMKII activation, and involved protein trafficking through specific PDZ domains of GIRK2c and GIRK3 subunit isoforms. Prolonged tonic firing may thus enhance the probability to switch into burst-firing mode, which then potentiates GIRK currents and favors the return to baseline. In conclusion, activitydependent GIRK channel plasticity may represent a slow destabilization process favoring the switch between the two firing modes of VTA DA neurons.

Key words: dopamine neuron; G-protein-coupled receptors; GIRK channels; phasic/tonic firing; plasticity; slow inhibition

\section{Introduction}

G-protein-coupled inwardly rectifying potassium (GIRK) channels are effectors of $\mathrm{G}_{\mathrm{i} / \mathrm{o}}$-protein-coupled receptors (Pfaffinger et al., 1985; Andrade et al., 1986). Four GIRK subunits have been identified (GIRK1-4; (Dascal et al., 1993; Kubo et al., 1993; Lesage et al., 1994; Krapivinsky et al., 1995), assembling as homo- or hetero-tetramers. $\mathrm{GABA}_{B}$ receptors $\left(\mathrm{GABA}_{\mathrm{B}} \mathrm{R}\right)$, composed of $\mathrm{GABA}_{\mathrm{B}} 1$ and $\mathrm{GABA}_{\mathrm{B}} 2$ subunits, activate GIRK channels to generate IPSCs, which mediate slow inhibition (Dutar and Nicoll, 1988; Lüscher et al., 1997). Glutamate and other neuromodulators, e.g., dopamine, adenosine, and serotonin, also activate GIRK channels via their cognate metabotropic receptor (Lüscher et al., 1997). GIRK channels therefore represent an important target for the modulation of neuronal function (Lujan et al., 2014).

Received Dec. 10, 2013; revised Feb. 7, 2014; accepted Feb. $27,2014$.

Author contributions: A.L.L., C.B., P.A.S., C.L., and K.R.T. designed research; A.L.L., M.B.M., and K.R.T. performed research; A.L.L. and K.R.T. analyzed data; A.L.L., C.L., and K.R.T. wrote the paper.

This work was funded by grants from the Swiss National Science Foundation to K.R.T. (Ambizione grant) and C.L. (Sinergia grant), the National Institute on Drug Abuse (Ruth L. Kirschstein National Research Service Award F31 DA029401 to M.B.M), Salk Institute Chapman Foundation to M.B.M., and the National Institute on Drug Abuse (DA025236) to P.A.S.. We thank Meaghan C. Creed and Sandrine Lefort for critical reading of the manuscript, and Matthew T. C. Brown for technical suggestions.

The authors declare no competing financial interests.

Correspondence should be addressed to either of the following: Christian Lüscher, Department of Basis Neurosciences, Medical Faculty, University of Geneva, rue Michel Servet 1, CH-1211 Geneva, Switzerland, E-mail: christian.luscher@unige.ch; or Kelly R. Tan, Department of Basis Neurosciences, Medical Faculty, University of Geneva, rue Michel Servet 1, CH-1211 Geneva, Switzerland, E-mail: Kelly.Tan@unige.ch.

DOI:10.1523/JNEUROSCI.5203-13.2014

Copyright $\odot 2014$ the authors $\quad 0270-6474 / 14 / 345107-08 \$ 15.00 / 0$
While GIRK channel inhibitory function is well recognized, we know little about the plasticity of the slow IPSC. It has been shown that pairing glutamate release with postsynaptic depolarization potentiates $\mathrm{GABA}_{\mathrm{B}} \mathrm{R}$-mediated slow IPSCs in hippocampal CA1 neurons (Huang et al., 2005). This plasticity was shown to depend on NMDA receptor (NMDAR) activation, $\mathrm{Ca}^{2+}$, and CaMKII, but the expression mechanism remains elusive. Studies in cultured hippocampal neurons reported that pharmacological activation of NMDAR leads to smaller $\mathrm{GABA}_{\mathrm{B}} \mathrm{R}$-evoked currents, relying on CaMKII actions on $\mathrm{GABA}_{\mathrm{B}} \mathrm{R}$ subunit 1 (Guetg et al., $2010)$ and protein phosphatase 2 (PP2A) on $\mathrm{GABA}_{\mathrm{B}} \mathrm{R}$ subunit 2 (Terunuma et al., 2010), respectively. Two recent studies further revealed that $\mathrm{PP} 2 \mathrm{~A}$-mediated internalization of $\mathrm{GABA}_{\mathrm{B}} \mathrm{R}$ led to cointernalization of GIRK channels and increased membrane excitability (Padgett et al., 2012; Hearing et al., 2013). Moreover, GIRK channel phosphorylation levels also affect their surface expression (Chung et al., 2009a,b). Altogether these studies suggest that GIRK channels are capable of plastic adaptations, but mechanistic insight is lacking. Here we assess the induction criteria for GIRK plasticity in dopamine (DA) neurons of the ventral tegmental area (VTA) and explore its expression mechanism.

GIRK channels are highly expressed in VTA DA neurons, where they allow activity modulation by $\mathrm{GABA}_{\mathrm{B}} \mathrm{R}$ (Johnson and North, 1992; Erhardt et al., 2002; Cruz et al., 2004) and DA type 2 receptor (D2R; Lacey et al., 1987; Kim et al., 1995). D2R are autoreceptors through which dendritically released DA provides a negative feedback signal and decreases DA neuron spontaneous firing (Beckstead et al., 2004; Gantz et al., 2013). In vivo, DA 
neurons fire either in a low tonic or higher bursting and phasic fashion (Grace and Bunney, 1984a,b). Bursting activity is believed to depend on NMDAR activation (Overton and Clark, 1992; Zweifel et al., 2011); however, it is not known whether adaptations occur at the level of the slow inhibition in DA neurons, which therefore would act as a slow destabilizing process responding to these abrupt firing changes.

In this study, we report bidirectional slow IPSC plasticity in the form of burst firing-induced potentiation and tonic firinginduced depression of GIRK currents, affecting both $G_{A B A} R$ and $\mathrm{D} 2 \mathrm{R}$ function. The potentiation requires NMDAR activation, intracellular $\mathrm{Ca}^{2+}$ and CaMKII activation. Furthermore, we show that expression of both potentiation and depression relies on protein trafficking via specific PDZ domains of both GIRK2c and GIRK3 subunits.

\section{Materials and Methods}

Animals. C57BL/6 male or female mice were bred locally and housed under constant temperature and humidity on a $12 \mathrm{~h}$ light/dark cycle with food and water ad libitum. Pitx3-GFP (Zhao et al., 2004) is a knock-in mouse that was kindly provided by Meng Li, Imperial College London. All procedures were performed in the light cycle and complied with the Veterinary Office of Geneva guidelines for animal handling at University of Geneva and the Salk Institute.

Electrophysiology in acute slices. Mice were killed and horizontal slices from midbrain $(250 \mu \mathrm{m})$ were prepared in ice-cold artificial CSF (ACSF) containing the following (in $\mathrm{mM}$ ): $119 \mathrm{NaCl}, 2.5 \mathrm{KCl}, 1.3 \mathrm{MgCl}_{2}, 2.5$ $\mathrm{CaCl}_{2}, 1 \mathrm{NaH}_{2} \mathrm{PO}_{4}, 26.2 \mathrm{NaHCO}_{3}$, and 11 glucose, $\mathrm{pH} 7.3$, continuously bubbled with $95 / 5 \% \mathrm{O}_{2} / \mathrm{CO}_{2}$. Slices were warmed to $33^{\circ} \mathrm{C}$ and incubated for $30 \mathrm{~min}$, then transferred to the recording chamber superfused with $\operatorname{ACSF}(2.5 \mathrm{ml} / \mathrm{min})$ at $\sim 33^{\circ} \mathrm{C}$. Epifluorescence with a U-LH100HG mercury lamp (Olympus) was used to visualize GFP and whole-cell patchclamp recordings were made from DA neurons in the VTA, identified as the region medial to the medial terminal nucleus of the accessory optical tract. When using non-GFP mice, DA neurons were identified by the presence of an $I_{h}$ current and a large capacitance $(40-100 \mathrm{pF})$. All currents were measured with an internal solution containing the following (in mM): $140 \mathrm{~K}$-gluconate, $5 \mathrm{KCl}, 2 \mathrm{MgCl}_{2}, 0.2$ EGTA, 10 HEPES, 4 $\mathrm{Na}_{2} \mathrm{ATP}, 10$ creatine-phosphate, and $0.3 \mathrm{Na}_{3} \mathrm{GTP}$. All synaptic currents were recorded in the presence of NBQX $(10 \mu \mathrm{M})$ and sulpiride $(200 \mathrm{nM})$ for $\mathrm{GABA}_{\mathrm{A}} \mathrm{R}$ IPSC, and picrotoxin $(100 \mu \mathrm{M})$ for $\mathrm{GABA}_{\mathrm{B}} \mathrm{R}$ slow IPSC. Baclofen, quinpirole, and GTP $\gamma \mathrm{S}$-evoked currents were measured in the absence of any specific antagonist. APV was used at $50 \mu \mathrm{M}$ to antagonize the NMDAR-mediated currents. The $\mathrm{Ca}^{2+}$ chelator BAPTA was used at $10 \mathrm{~mm}$. The stimulation electrode consisted of a saline-filled monopolar glass pipette, placed caudally to the cell being recorded. $\mathrm{GABA}_{\mathrm{A}} \mathrm{R}$ pairedpulse ratio (PPR) was assessed by applying two pulses at $50 \mathrm{~ms}$ interval, every $10 \mathrm{~s}$, whereas the $\mathrm{GABA}_{\mathrm{B}} \mathrm{R}$ slow IPSC was evoked by a train of 10 electrical pulses at $66 \mathrm{~Hz}$, once every $20-40 \mathrm{~s}$. The decay time kinetic of the slow IPSC was measured as weighted tau $\left(\tau_{w}\right)$ following a double exponential fitting. Caged GTP $\gamma \mathrm{S}$ was photolyzed by flashing UV light for $2 \mathrm{~s}$ on the slice. Currents were filtered at $1 \mathrm{kHz}$ and digitized at $5 \mathrm{kHz}$ (National Instruments PCI-MIO-16E-4 card) and saved on the computer (IGOR Pro; WaveMetrics). Cells were clamped at $-60 \mathrm{mV}$. Cell membrane and access resistance were measured with each sweep. All chemicals for electrophysiology were purchased from Tocris Bioscience except caged GTP $\gamma S$ (Invitrogen). We did not observe any differences between wild-type and Pitx3-GFP mice, therefore, we pooled the data. Data are expressed as mean \pm SEM and statistical significance $\left({ }^{*} p<0.05\right.$, ${ }^{* *} p<0.01,{ }^{* *} p<0.001$, and $\left.{ }^{* * *} p<0.0001\right)$ was determined by Student's $t$ test or one-way ANOVA. The extent of the plastic changes was calculated at the last $5 \mathrm{~min}$ of the recording or right before the second protocol was applied in the case of occlusion experiments. Sequence of the peptides is as follows: "GIRK3 PDZ": LPPPESESKV C-terminal domain; "control": LPPPAAAAAA control for GIRK3; GIRK2c: VANLENESKV C-terminal domain.
A

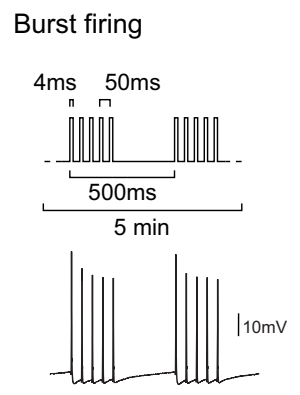

B
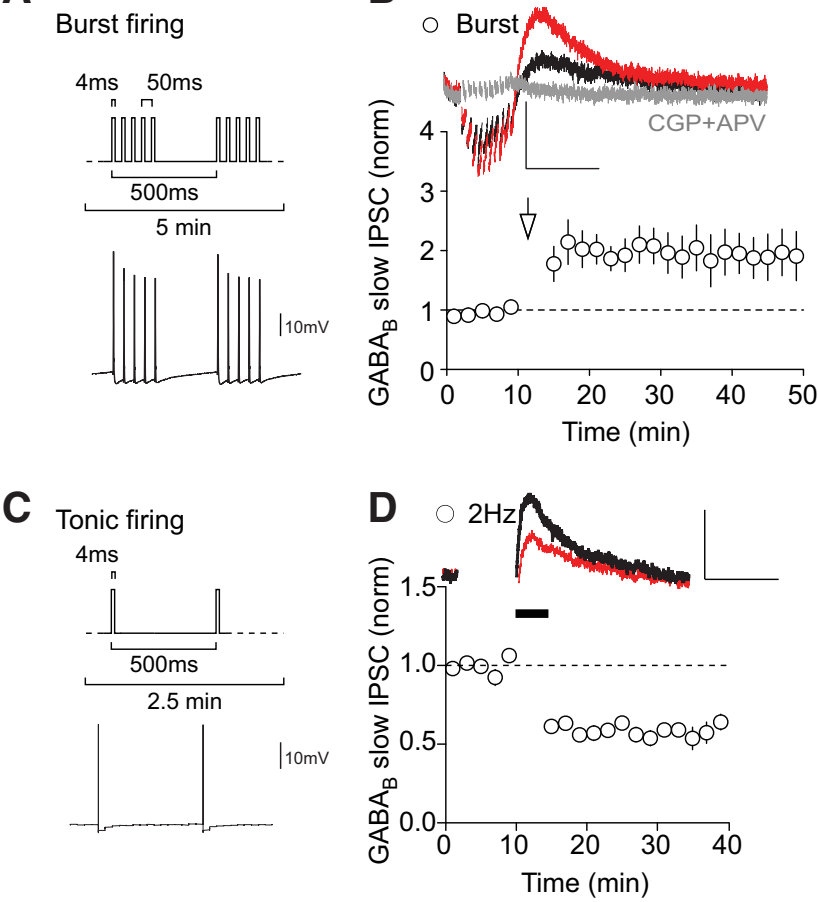

Figure 1. Activity of VTA DA neurons triggers plasticity of the slow IPSC. A, Phasic burst firing protocol representation (burst applied at $20 \mathrm{~Hz}$, each burst consists of $5 \times 4$ ms pulse at $50 \mathrm{~Hz}$, every $500 \mathrm{~ms}$, for $5 \mathrm{~min}, I=0$ ) and example trace of action potential evoked at each current pulse (bottom). $\boldsymbol{B}$, The GABA ${ }_{B}-$ GIRK slow IPSC is potentiated after the burst protocol (open arrow, $n=8,2 \mathrm{~min}$ bin). Insets, Example average traces show the slow IPSC at baseline (black trace) and 20 min post protocol (red trace) blocked by CGP54626 (2 $\mu \mathrm{m}$, gray trace). APV (50 $\mu \mathrm{M}$ ) blocked the fast inward NMDAR component that is generated by the $66 \mathrm{~Hz}$ stimulation (artifact was removed for clarity purpose). C, Tonic firing protocol representation (horizontal bar, $4 \mathrm{~ms}$ pulses applied at $2 \mathrm{~Hz}$ for $2.5 \mathrm{~min}, I=0$ ) and example trace of evoked firing. $\boldsymbol{D}$, Tonic firing of VTA DA cells depresses the amplitude of GABA ${ }_{B}-$ GIRK slow IPSC ( $n=8,2$ min bin). Insets, Example average traces of slow IPSCs recorded before (black trace) and after the protocol (red trace). Calibration: 20 pA, 200 ms.

\section{Results}

\section{Activity of VTA DA neurons induces plasticity of the slow IPSC}

We first investigated whether the two modes of activity of VTA DA neurons (Fig. 1 $A, C$ ) affect the slow IPSC. We prepared horizontal slices containing the VTA and recorded from identified DA neurons (Pitx3-GFP mice; Zhao et al., 2004). Electrical stimulation (10 pulses at $66 \mathrm{~Hz}$; Padgett et al., 2012) elicited a stable outward slow IPSC in the presence of $\mathrm{GABA}_{\mathrm{A}} \mathrm{R}, \mathrm{AMPA}$ receptors (AMPAR) and D2R antagonists (Fig. $1 B$ ). This slow IPSC was sensitive to CGP54626, a selective high-affinity $\mathrm{GABA}_{\mathrm{B}} \mathrm{R}$ antagonist. Imposing high-frequency bursting to the recorded DA neuron (5-pulse $20 \mathrm{~Hz}$ burst, every $500 \mathrm{~ms}$ for $5 \mathrm{~min}$, in currentclamp mode $I=0$; Fig. $1 A$ ), mimicking the burst firing recorded in vivo during rewarding stimuli (Hyland et al., 2002), we observed a long-lasting potentiation of the slow IPSC (192 $\pm 38 \%$ of baseline; Fig. $1 B$ ). This did not affect the decay time kinetic of the slow IPSC measured as weighted tau $\left(\tau_{w \text { before }} 268 \pm 74\right.$ vs $\tau_{\text {wafter }}$ $\left.297 \pm 71, t_{(12)}=0.28, p=0.78\right)$. We then asked whether DA neurons could downregulate the $\mathrm{GABA}_{\mathrm{B}}$-GIRK slow inhibition in a situation of tonic activity (McCutcheon et al., 2012). We imposed tonic firing to the patched DA neurons $(2 \mathrm{~Hz}$ for 2.5 min, in current-clamp mode $I=0$; Fig. $1 C$ ). This resulted in a significant decrease of the slow IPSC amplitude (60 $\pm 3 \%$ of baseline; Fig. $1 D$ ) with no change in the decay time kinetic of the 
A
Depolarization
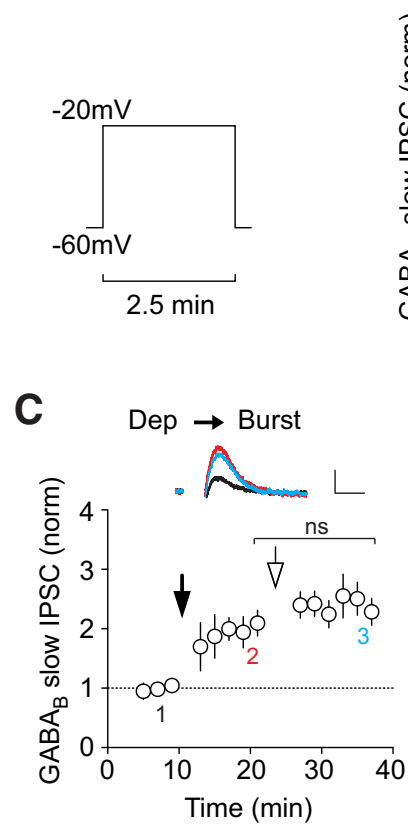

E

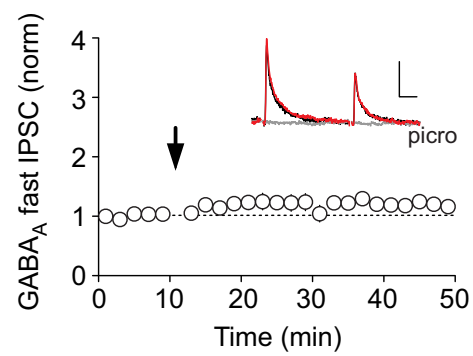

○ Dep

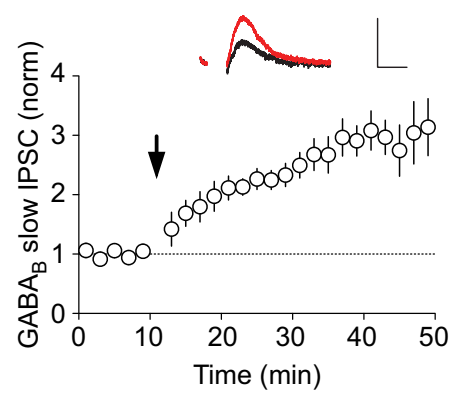

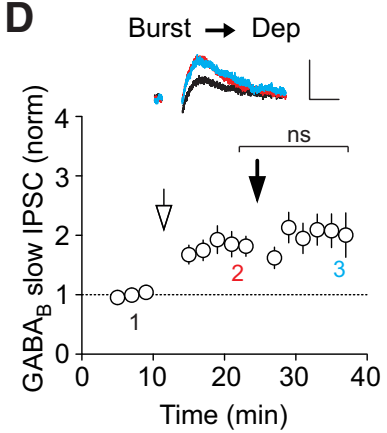

F

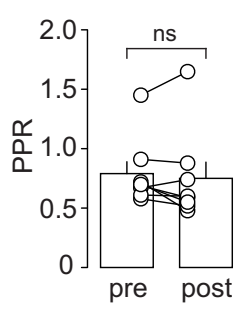

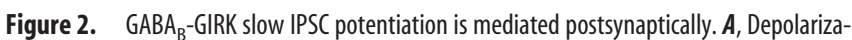
tion protocol representation ( $2.5 \mathrm{~min}$ at $-20 \mathrm{mV}$ ). $\boldsymbol{B}$, The GABA $\mathrm{B}_{\mathrm{B}}$-GIRK slow IPSC is potentiated after neuronal depolarization (Dep; closed arrow, $n=10$ ). C, Further potentiation is occluded when the burst protocol (open arrow) is applied after the depolarization protocol $(n=7)$. $\boldsymbol{D}$, The opposite manipulation also resulted in no further potentiation of the slow IPSCs $(n=6)$. $\boldsymbol{E}$, Outward $\mathrm{GABA}_{A}$ receptor-mediated current amplitude does not change after the depolarization protocol $(n=8)$. The current is blocked by picrotoxin (100 $\mu \mathrm{m}$, gray trace). $\boldsymbol{F}, \mathrm{PPR}$, measured at a 50 ms interval, is not affected. Insets, Example average traces of the slow IPSC before (black) and after (red) the first protocol. Blue traces are example average IPSC after the second protocol is applied. Calibration: slow IPSC, 20 pA, $200 \mathrm{~ms}$; fast IPSC, 20 pA, $10 \mathrm{~ms}$.

slow IPSC ( $\tau_{\text {wbefore }} 264 \pm 56$ vs $\tau_{\text {wafter }} 275 \pm 50, t_{(8)}=0.16, p=$ $0.88)$. These data suggest that $G_{A B A}$-GIRK can undergo bidirectional plastic changes; the currents were potentiated in response to high neuronal activity, and depressed in conditions mimicking tonic activity.

Since burst activation depolarizes the cells, we tested whether the sole depolarization of the recorded neurons from -60 to -20 $\mathrm{mV}$ for $2.5 \mathrm{~min}$ (Fig. $2 \mathrm{~A}$ ) could also potentiate the slow IPSC. This indeed led to an increase in the amplitude of the $\mathrm{GABA}_{\mathrm{B}}{ }^{-}$ GIRK slow IPSC ( $278 \pm 61 \%$ of baseline; Fig. $2 B$ ) with no change in the decay time kinetic of the slow IPSC $\left(\tau_{\text {wbefore }} 263 \pm 64\right.$ vs $\left.\tau_{\text {wafter }} 272 \pm 69, t_{(14)}=0.008, p=0.93\right)$. However, the development of this depolarizing-induced potentiation exhibited a different kinetic compared with the one induced by the burst protocol. To assess whether these two protocols share common induction pathways, we performed occlusion experiments where

the depolarization protocol was first applied then followed by burst protocol $\left(203 \pm 23 \%\right.$ then $248 \pm 29$ of baseline, $t_{(12)}=1.20$, $p=0.25$; Fig. $2 C$ ). The opposite procedure was also tested (187 \pm $20 \%$ then $206 \pm 29 \%$ of baseline, $t_{(10)}=1.20, p=0.55$; Fig. $2 D$ ). In each case, no further significant potentiation of the slow IPSC was observed, indicating that both protocols share parts of the same molecular mechanism for the slow IPSC potentiation. We also measured $\mathrm{GABA}_{\mathrm{A}} \mathrm{R}$-mediated fast-kinetic responses before and after the depolarization protocol. Neither the amplitude (105 $\pm 8 \%$ of baseline; Fig. $2 E$ ) nor the PPR was modified (PPR pre, $0.79 \pm 0.10$; PPR post, $0.75 \pm 0.14, t_{(14)}=0.23, p=0.82$; Fig. $2 F)$. These data suggest that the increase of GABA-mediated inhibition onto DA neurons following protocols mimicking sustained activity is mediated postsynaptically and is specific to the slow inhibition induced by $\mathrm{GABA}_{\mathrm{B}}$-GIRK complexes.

\section{Slow IPSC potentiation requires protein surface delivery}

In hippocampal CA1 neurons, induction of slow IPSC potentiation shares molecular pathways with AMPAR long-term potentiation (Huang et al., 2005). We tested this possibility in VTA DA neurons. Both bath application of APV and intracellular BAPTA blocked the depolarization-induced slow IPSC potentiation, compared with control experiments (control dep., open circles, $303 \pm 33 \%$ of baseline; APV, closed circles, $101 \pm 17 \%$ of baseline, $t_{(13)}=4.68, p=0.0004$; BAPTA, gray circles, $102 \pm 7 \%$ of baseline, $t_{(15)}=5.6, p<0.0001$; Fig. $3 A$ ). Furthermore, inhibiting CaMKII with intracellular KN93 also prevented the increase in the slow IPSC amplitude, whereas the inactive equivalent KN92 had no effect (KN93, closed circles, $81 \pm 7 \%$ of baseline; KN92, open circles, $260 \pm 46 \%$ of baseline, $t_{(10)}=3.22, p=0.009$; Fig. $3 B)$. These results confirm that the induction of the slow IPSC potentiation in the VTA, just as in the hippocampus, relies on the activation of NMDAR, leading to an increased intracellular $\mathrm{Ca}^{2+}$ concentration and CaMKII activation.

A possible scenario underlying the expression of the slow IPSC potentiation could be an increase in the number of receptors or channels on the cell surface. To test for the requirement of protein exocytosis, we added tetanus toxin (TeTx) to the recording pipette and dialyzed the cells for $20 \mathrm{~min}$. TeTx had no effect on basal slow IPSC amplitude (data not shown), but blocked the potentiation of the current, which was intact when a heatinactivated variant of the toxin was used (TeTx, closed circles, $85 \pm 11 \%$ of baseline; inact. TeTx, open circles, $210 \pm 13 \%$ of baseline, $t_{(11)}=7.38, p<0.0001$; Fig. $\left.3 C\right)$. These results demonstrate the necessity of protein trafficking and insertion at the membrane, and suggest that $\mathrm{GABA}_{\mathrm{B}} \mathrm{R}$, GIRK channels, or both are subjected to this trafficking.

\section{Slow IPSC potentiation relies on GIRK channel plasticity}

To further investigate whether the $\mathrm{GABA}_{\mathrm{B}} \mathrm{R}$ or the GIRK channel or both are trafficked to the membrane, we asked whether the slow IPSC potentiation was selective for $\mathrm{GABA}_{\mathrm{B}} \mathrm{R}$ to GIRK channel signaling or also affected DA D2R currents. To this end we compared the currents generated by bath application of specific agonists for $\mathrm{GABA}_{\mathrm{B}} \mathrm{R}$ and the D2R. First, $\mathrm{GABA}_{\mathrm{B}}$-GIRK currents were induced with bath application of a saturating concentration of baclofen $(300 \mu \mathrm{M})$ and monitored for $20 \mathrm{~min}$. These agonistevoked currents displayed the typical DA neuron-specific desensitization (Cruz et al., 2004) and were blocked by CGP54626 (gray trace and bar, $289 \pm 16$ pA; Fig. 4A). In separate slices, baclofen-evoked currents measured after the depolarization protocol (see above) were significantly larger than control (red trace and bar, $498 \pm 74 \mathrm{pA}, t_{(25)}=2.30, p=0.030$; Fig. $4 A$ ). Again, 
bath application of APV blocked the potentiation (open bar, $253 \pm 39 \mathrm{pA}, t_{(24)}=$ 2.47, $p=0.021$; Fig. $4 A$ ). We next repeated this sequence of experiments with a saturating concentration of quinpirole $(40 \mu \mathrm{M})$, a specific D2R agonist. Quinpirole evoked highly desensitizing currents that were blocked by sulpiride, a specific D2R antagonist (gray trace and bar, $98 \pm 11$ pA; Fig. 4B). Again, quinpirole-evoked currents were significantly larger after depolarization of the cell (red trace and bar, $200 \pm 34 \mathrm{pA}, t_{(25)}=2.97$, $p=0.003$; Fig. $4 B$ ), and the potentiation was also blocked by APV (open bar, $112 \pm$ $27 \mathrm{pA}, t_{(21)}=1.94, p=0.033$; Fig. $\left.4 B\right)$. These results indicate that the potentiation of the slow inhibition is not restricted to the $\mathrm{GABA}_{\mathrm{B}}$-GIRK pathway, but overlaps with other neurotransmitter systems, strongly suggesting a plasticity of GIRK channel, independently of the GPCR involved. If this is the case, then direct activation of GIRK channels, bypassing GPCR activation, should also be potentiated after application of the depolarization protocol. To test this, we used the photo-caged version of the nonhydrolyzable GTP $\gamma \mathrm{S}$. UV-flash photolysis allows fast, receptor-independent Gprotein activation, which evoked large desensitizing currents that were blocked by $\mathrm{Ba}^{2+}$, a nonspecific $\mathrm{K}^{+}$channel blocker (gray trace and bar, $465 \pm 55$ pA; Fig. 4C). As predicted, the depolarization protocol potentiated GIRK currents, which at baseline were larger than baclofen-evoked currents in line with a complete recruitment of all channels in the cell (red trace and bar, $825 \pm 104 \mathrm{pA}, t_{(23)}=2.99, p=$ 0.006; Fig. $4 C$ ). Similar to the potentiation induced by activation of $\mathrm{GABA}_{\mathrm{B}} \mathrm{R}$ and D2R, APV was able to block the plasticity induced by the sole activation of GIRK channels (open bar, $519 \pm$ $82 \mathrm{pA}, t_{(21)}=2.21, p=0.038$; Fig. $4 C$ ). This experiment confirms that the potentiation of the slow IPSC is expressed by GIRK channel-specific trafficking.

\section{GIRK current potentiation requires GIRK2c and GIRK3 PDZ domains}

VTA DA neurons are unique in that they express GIRK2c and GIRK3 subunit isoforms but not GIRK1 (Cruz et al., 2004). Therefore, functional channels of DA neurons are composed of either GIRK2c-GIRK3 heteromers or GIRK2 homomers. To identify the subunit composition of GIRK channels involved in the slow IPSC potentiation, we recorded $G_{A B A}$-GIRK currents in the GIRK3 KO mouse (Torrecilla et al., 2002). As previously shown in the substantia nigra pars compacta DA neurons (Koyrakh et al., 2005), baclofen-evoked currents are of similar amplitude despite the absence of GIRK3 subunit (gray trace and bar, $273 \pm 38$ pA; Fig. 5A). However, the depolarization protocol no longer led to the potentiation of the baclofen-evoked current (red trace and bar, $300 \pm 46 \mathrm{pA}, t_{(11)}=0.46, p=0.66$; Fig. $5 A$ ),
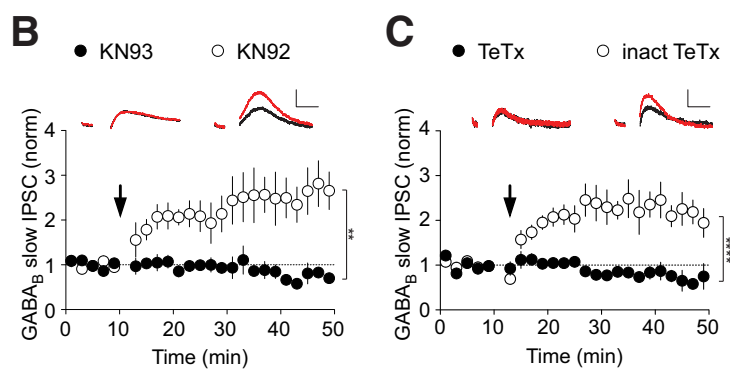

Figure 3. The slow IPSC potentiation requires surface protein delivery. $A$, The depolarization (Dep) protocol (closed arrow) potentiating $\mathrm{GABA}_{B}-$ GIRK slow IPSCS (open circles, $n=10$ ) has no effect when either APV is bath applied ( $50 \mu \mathrm{m}$, closed circles, $n=9$ ) or when BAPTA is added to the recording solution (10 mm, gray circles, $n=7$ ). $\boldsymbol{B}, \mathrm{KN} 93$, an inhibitor of CaMKIl, blocks the

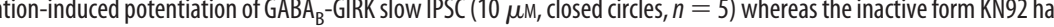
, whereas the heat-inactivated (inact.) toxin had no effect (open circles, $n=6$ ), indicating a requirement for protein trafficking. Insets, Example average traces of the slow IPSC before (black) and after (red) the depolarization protocol.

A

Figure 4. The slow IPS ( potentiation relies on GIRK channel plasticity. $A$, Maximal baclofen-evoked (baclo) GABA ${ }_{B}-G I R K$ current 列 no protocol (gray, $n=12)$, but not in the presence of APV $(50 \mu m, n=10)$. Insets, Example average traces of the slow IPSC before (gray, control, ctrl) and after (red) the depolarization protocol. Calibration: 200 pA, 5 min. arguing for a critical role of GIRK2c-GIRK3 heteromers in the expression of the slow IPSC potentiation. Both GIRK2c and GIRK3 exhibit a PDZ binding in their C-terminal tail that has been implicated in their trafficking (Lunn et al., 2007; Balana et al., 2011). We hypothesized that these motifs may be implicated in the expression of the GIRK current potentiation. To verify this we designed specific dominant-negative peptides for the PDZ domain of GIRK2c or GIRK3 subunits. As shown previously, these peptides bind to and prevent interactions of PDZ binding proteins specifically with GIRK2c and GIRK3 (Balana et al., 2011). We added the peptide to the recording pipette and infused neurons for $20 \mathrm{~min}$ before applying the depolarization protocol. The presence of both GIRK2c and GIRK3 dominant-negative peptide did not affect basal slow IPSC amplitude (data not shown), but blocked the potentiation of the synaptically evoked current, whereas a scrambled control peptide had no effect (control, open circles, $257 \pm 55 \%$ of baseline, GIRK3, closed circles, $93 \pm 13 \%$ of baseline, $t_{(16)}=3.11, p=0.0068$; GIRK $2 c$, gray symbols, $109 \pm 12 \%$ of baseline, $t_{(15)}=2.49, p=0.025$; Fig. $5 B$ ). We conclude that both GIRK2c and GIRK3 subunit isoforms are 
A GIRK3 KO

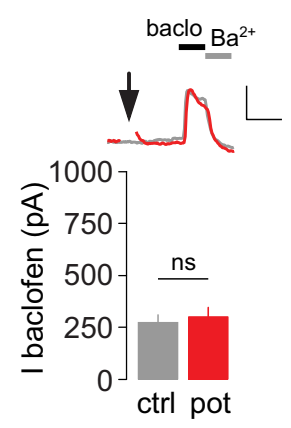

B Dominant negative peptide

-GIRK3 PDZ •GIRK2c PDZ Octrl

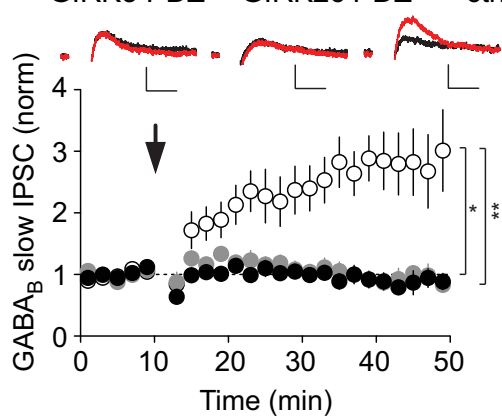

Figure 5. GIRK current potentiation requires trafficking through PDZ binding domains on GIRK2c and GIRK3 subunit isoforms. $A$, Maximal baclofen-evoked (baclo) $G_{A B A}$-GIRK current is not potentiated after the depolarization protocol (closed arrow) in DA neurons from GIRK3 KO mice (300 $\mu \mathrm{M}$, gray, $n=6$ vs red, $n=7)$. The current is antagonized by Ba ${ }^{2+}(1 \mathrm{~mm})$. Calibration: $200 \mathrm{pA}, 5 \mathrm{~min}$. $\boldsymbol{B}$, Infusing the cell with a dominant-negative peptide for PDZ domain of GIRK3 (closed circles, $n=12$ ) and GIRK2C (gray circles, $n=8$ ) blocked the potentiation, whereas a control (ctrl) peptide had no effect (open circles, $n=9$ ). Insets, Example average traces of the slow IPSC before (black) and after (red) the depolarization protocol. Calibration: $20 \mathrm{pA}, 200 \mathrm{~ms}$.

required for the expression of the $\mathrm{GABA}_{\mathrm{B}}$-GIRK slow IPSC potentiation, which occurs through specific PDZ domain interaction on both subunit isoforms.

Alternate mode firing is sufficient to reverse GIRK plasticity The slow IPSC is potentiated in response to high, burst-like neuronal activity and depressed in conditions mimicking tonic activity (Fig. 1). In the next set of experiments, we tested the ability of low-frequency stimulation (LFS; $2 \mathrm{~Hz}$ ) to acutely reverse the depolarization-induced slow IPSC potentiation. In this case LFS was applied on the slice to electrically stimulate glutamatergic axon terminals, thereby evoking NMDAR-mediated currents, blocked by APV and mimicking a tonic activity in DA neurons (Fig. 6A). LFS induced a sustained depression of the amplitude of the slow IPSC, which was blocked in the presence of APV $(2 \mathrm{~Hz}$, open circles, $48 \pm 6 \%$ of baseline; APV, closed circles, $106 \pm 17 \%$ of baseline, $t_{(7)}=3.5, p=0.010$; Fig. $\left.6 B\right)$. The decay time of the slow IPSC was not modified $\left(\tau_{\text {wbefore }} 213 \pm 44\right.$ vs $\tau_{\text {wafter }} 283 \pm 53$, $\left.t_{(10)}=0.43, p=0.68\right)$. Such depression is most likely postsynaptically expressed since LFS did not affect the release probability of GABA. Indeed, neither the amplitude of the $\mathrm{GABA}_{\mathrm{A}} \mathrm{R}$-mediated fast IPSCs $(110 \pm 13 \%$ of baseline; Fig. $6 C)$ nor the PPR was modified by the LFS protocol (PPR pre, $0.71 \pm 0.04$; PPR post, $0.72 \pm 0.06, t_{(10)}=0.24, p=0.82$; Fig. $\left.6 D\right)$. We next addressed the question of a potential internalization of GIRK channels via their PDZ binding domains (Balana et al., 2011). To do so we recorded the amplitude of the slow IPSC before and after the LFS, in the presence of the GIRK3 PDZ dominant-negative peptide. In these conditions the LFS protocol failed to induce the slow IPSC depression, whereas a scrambled control peptide did not affect the magnitude of the LTD (GIRK3, closed circles, $95 \pm 4 \%$ of baseline, control, open circles, $57 \pm 2 \%$ of baseline, $t_{(9)}=8.9, p<$ $0.0001 ;$ Fig. $6 E$ ). These data suggest that similarly to the potentiation of the slow IPSC, its depression also relies on PDZ domaindependent GIRK channel trafficking.

In a last set of experiments, after eliciting a stable slow IPSC, we first applied the depolarization protocol and recorded an increase in the amplitude of the slow IPSC (after depolarization, red trace, $230 \pm 22 \%$ of baseline; Fig. $6 F$ ). We then allowed $10 \mathrm{~min}$ of
A
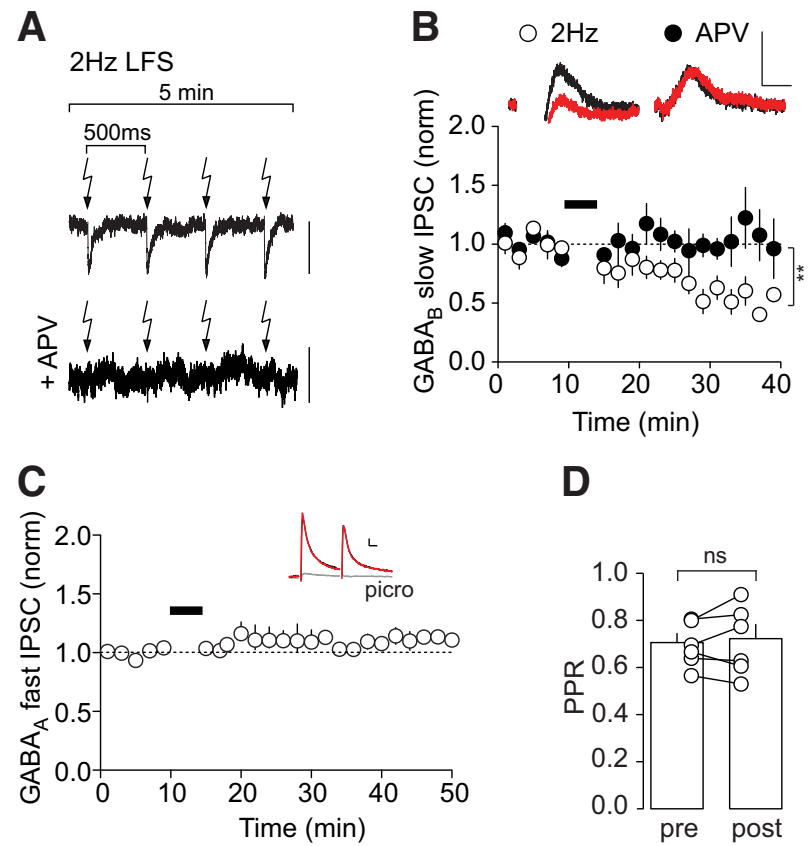

D
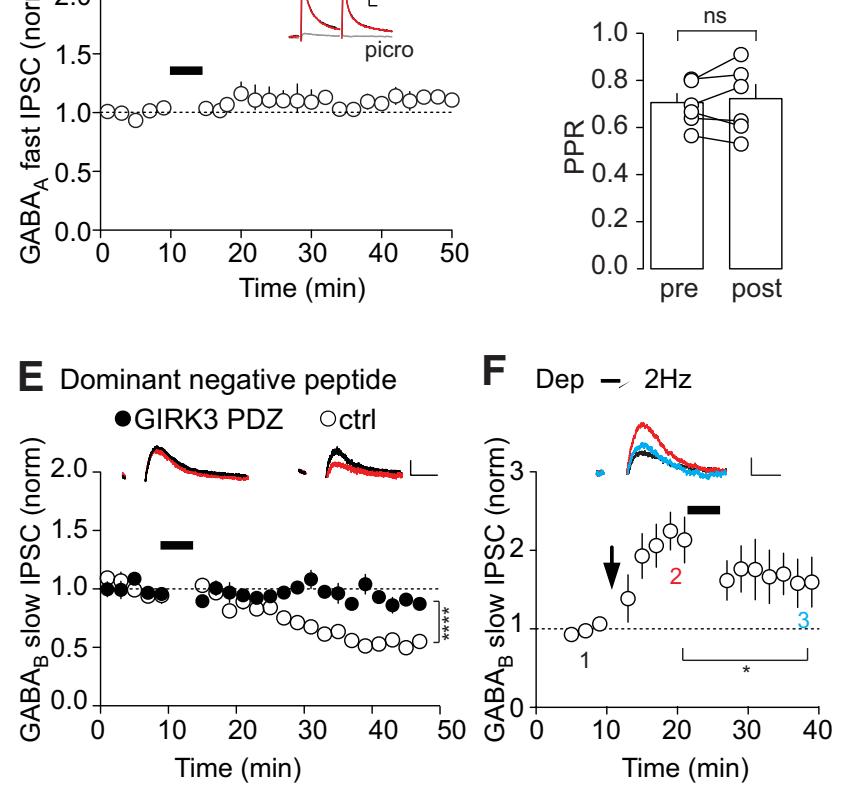

Figure 6. The slow IPSC plasticity responds to VTA DA neuron activity state. A, Lowfrequency stimulation protocol representation (LFS $2 \mathrm{~Hz}$ for $5 \mathrm{~min}$ ) and example traces of NMDAR-mediated current, blocked by APV $(50 \mu \mathrm{M})$, at each electrical pulse (bottom; calibration $20 \mathrm{pA}) \cdot \boldsymbol{B}$, The GABA ${ }_{B}$-GIRK slow IPSC is depressed after the tonic stimulation protocol (black bar, $n=6$, open circles), but not in the presence of APV ( $n=4$, closed circles). C, Outward fast $\mathrm{GABA}_{\mathrm{A}}$ receptor-mediated current amplitude does not change after the LFS protocol $(n=6)$. The current is blocked by picrotoxin (picro; $100 \mu \mathrm{m}$, gray trace). D, PPR, measured at a $50 \mathrm{~ms}$ interval, is not affected. $\boldsymbol{E}$, Infusing the cell with the dominant-negative peptide for PDZ domain of GIRK3 (closed circles, $n=6$ ) blocked the depression, whereas the control peptide had no effect (open circles, $n=5$ ). $\boldsymbol{F}$, After a depolarization-induced (Dep) potentiation (closed arrow), tonic $2 \mathrm{~Hz}$ stimulation (horizontal bar) depotentiates the $\mathrm{GABA}_{B}$-GIRK slow IPSC $(n=5)$. Insets, Example average traces of the slow/fast IPSC before (black) and after (red) the protocol. Blue trace is an example average of the slow IPSC after the second protocol is applied. Calibration: slow IPSC, 20 pA, $200 \mathrm{~ms}$; fast IPSC, 20 pA, 10 ms.

stable potentiated slow IPSC before applying the LFS. In this case the LFS induced a partial but significant decrease of the slow IPSC amplitude (after $2 \mathrm{~Hz}$, blue trace, $157 \pm 23 \%$ of baseline, $t_{(8)}=$ $2.3, p=0.025$; Fig. $6 F$ ). These data demonstrate that the GIRK channel-mediated slow inhibition rapidly adapts to changes in response to DA neuronal activity.

\section{Discussion}

In the present study we observe the plasticity of GIRK currents as an intrinsic mechanism engaged in response to a switch in VTA DA neuron firing mode. We provide evidence for increased slow IPSC amplitude in response to burst firing and-mirroring these observations-a decrease of the slow IPSC amplitude following 
prolonged tonic firing. These protocols were also sufficient to reverse previously potentiated slow IPSCs (depotentiation). We characterize the underlying mechanism and show that it is independent of the GPCR activation, requires NMDAR and CaMKII, and is expressed by trafficking of channels containing the GIRK2c and GIRK3 subunit through interactions of specific PDZ domains.

\section{Expression of the slow IPSC potentiation involves increased GIRK surface insertion}

Given the constituent proteins generating the slow IPSC (GPCR, $\mathrm{G}_{\mathrm{i} / \mathrm{o}}$-protein and GIRK channel), its plasticity may involve several distinct expression mechanisms. A change in number of receptors and/or channels would affect the amplitude of the slow IPSC as well as the maximal agonist-evoked current (efficacy). Changing the coupling efficiency between receptor and effector, on the other hand, would also affect synaptic currents and reflect a potency change. An example of the former mechanism is the reduction of $\mathrm{GABA}_{\mathrm{B}} \mathrm{R}$ number at the cell surface (Guetg et al., 2010; Terunuma et al., 2010; Padgett et al., 2012) or the increase in GIRK2 channels in spines of hippocampal neurons leading to potentiated serotonin and adenosine-evoked current (Chung et al., 2009a; Nassirpour et al., 2010). Phosphorylation of GIRK subunits may change their intrinsic properties such as open channel probability, open state duration, or single channel conductance (Mao et al., 2004), again affecting efficacy. Potency changes involve regulator proteins of G-protein signaling type 2 (RGS2), which can decrease $\mathrm{GABA}_{\mathrm{B}}$-GIRK coupling in VTA DA neurons (Labouèbe et al., 2007). In general GIRK channels containing the GIRK1 subunit are more efficiently coupled to $G_{A B A} R$ than channels without this subunit (Cruz et al., 2004).

The manipulations performed in the present study change the amplitude of GIRK currents elicited with a saturating agonist concentration in line with a change of the number/function of GIRK channels. The fact that the GIRK channels mediate plasticity expression is further supported by the observation that both $\mathrm{GABA}_{\mathrm{B}}$ - and D2 receptor-mediated GIRK currents undergo potentiation with the depolarization protocol. Furthermore the GTP $\gamma \mathrm{S}$ experiments, where maximal currents were elicited independently of receptor activation, argue against a potency change. Finally, blocking the potentiation of the slow IPSC with TeTx indicates that trafficking of proteins to the surface is required and suggests a change in number or function of GIRK channels as the major expression mechanism.

\section{GIRK channel trafficking through PDZ domains}

An expression mechanism that relies on the delivery of specific subunit-containing GIRK channels is supported by our observation that the slow IPSC potentiation was absent in slices from GIRK3 KO mice. As shown previously, native GIRK currents in VTA DA neurons are carried by channels that contain the GIRK3 subunit, which has a C-terminal tail containing a PDZ binding domain implicated in GIRK channel trafficking (Lunn et al., 2007). We confirm this role with a dominant-negative peptide targeting this PDZ domain, which blocked both slow IPSC potentiation and depression, suggesting that the PDZ domain mediates bidirectional channel trafficking. Since a similar peptide-aimed at the corresponding domain on GIRK2c-also blocked the potentiation, the channels delivered are most likely GIRK2c/3 heteromers, suggesting an increase in the number of channels at the membrane. However, we cannot exclude that GPCR are also upregulated, as it was previously reported that internalization of $\mathrm{GABA}_{\mathrm{B}} \mathrm{R}$ could drag GIRK channels along, probably due to macrocomplex formation and proximity (Padgett et al., 2012).

Future studies will have to identify which proteins are responsible for binding GIRK subunits to drive their removal and insertion at the cell surface. G-protein-insensitive inwardly rectifying $\mathrm{K}^{+}$channels (kir2) bear similar PDZ domains and have been shown to be regulated by proteins of the postsynaptic density like SAP-97 and PSD-93, leading to increased stability at the membrane (Leonoudakis et al., 2004; Leyland and Dart, 2004). Despite high PDZ structure similarity, GIRK2c and GIRK3 do not interact with SAP-97 or PSD-95 (Hibino et al., 2000; Nehring et al., 2000). However, an interaction has been revealed with sorting nexin protein 27 (SNX27; Lunn et al., 2007), which specifically recognizes GIRK2c and GIRK3, but not Kir2.1 subunits (Balana et al., 2011). SNX27 has been reported to mediate both endosome-directed trafficking of GIRK channels and membrane trafficking of receptors like $\beta 2$-adrenoreceptor (Lauffer et al., 2010), and therefore represents a potential candidate in mediating GIRK channel plasticity.

\section{GIRK channel plasticity as a destabilization mechanism of neural firing mode}

Phasic-like activity is sufficient to potentiate the $\mathrm{GABA}_{\mathrm{B}}$-GIRK slow IPSC while tonic activity causes a depression. This bidirectional plasticity requires NMDAR activation, intracellular $\mathrm{Ca}^{2+}$, and CaMKII activation, which are hallmarks of glutamatergic transmission long-term potentiation induction (Nicoll and Roche, 2013). This suggests that the specificity for excitatory versus inhibitory plasticity may not reside in the main molecular machinery but in channel-specific trafficking or auxiliary proteins (Kullmann et al., 2012). However, the slow IPSC potentiation differs in several ways from the Hebbian mechanism of synaptic plasticity. First, it is not input specific or restricted to a specific set of synapses, since the potentiation can be revealed by $\mathrm{GABA}_{\mathrm{B}}$ and D2 receptors or direct GIRK channel activation. Second, it does not require input stimulation, as burst firing and depolarization were applied in the absence of any electrical stimulation. Third, rather than reinforcing a stimulated connection, this adaptation seems to work as a compensatory mechanism to provide a mean for DA neurons to hyperpolarize following an intense period of firing (mimicked by both sustained burst firing or prolonged depolarization). And, last, tonic activity in DA neurons depresses the GIRK-mediated slow IPSC, as observed following either $2 \mathrm{~Hz}$ firing imposed to the cell or $2 \mathrm{~Hz}$ electrical stimulation evoking NMDAR activation. This slow IPSC depression is also postsynaptically mediated and expressed through GIRK channel trafficking via their PDZ binding domain. Together these observations suggest an intrinsic compensatory mechanism to regulate neuronal activity and maintain it close to a certain threshold, where GIRK current plasticity would represent a slow destabilizing process through which VTA DA neurons regulate their bistability. This is reminiscent of synaptic scaling reported at the level of neurons and networks (Turrigiano et al., 1998; Turrigiano and Nelson, 2000). In other words, the slow IPSC modulation may be a form of homeostatic plasticity.

DA neurons are central to crucial brain processes such as motivation, learning, and reinforcement (Schultz, 2006; Grace et al., 2007; Bromberg-Martin et al., 2010). External sensory cues constantly modulate DA neuron activity, mostly through glutamatergic transmission, rapidly switching back and forth from tonic to phasic firing mode (Schultz, 1998; Hyland et al., 2002). Our results suggest that GIRK plasticity similarly follows changes in firing mode, as tonic activity acutely depotentiated previously 
potentiated GIRK currents. In this context, a homeostatic GIRK channel plasticity could allow DA neurons to adapt their excitability.

In conclusion, we have unraveled an activity-dependent and bidirectional plasticity of slow inhibition in VTA DA neurons. The expression of potentiation and depression is mediated by GIRK channel trafficking, independently of GPCR, demonstrating a functional role of PDZ domains on both GIRK2c and GIRK3 subunits. Future studies will have to identify precisely how this plasticity modulates VTA DA neuron activity, and whether adaptations in GIRK currents may provide a common compensatory mechanism across cell types and brain regions.

\section{References}

Andrade R, Malenka RC, Nicoll RA (1986) A G protein couples serotonin and $\mathrm{GABAB}$ receptors to the same channels in hippocampus. Science 234:1261-1265. CrossRef Medline

Balana B, Maslennikov I, Kwiatkowski W, Stern KM, Bahima L, Choe S, Slesinger PA (2011) Mechanism underlying selective regulation of $G$ protein-gated inwardly rectifying potassium channels by the psychostimulant-sensitive sorting nexin 27. Proc Natl Acad Sci U S A 108:5831-5836. CrossRef Medline

Beckstead MJ, Grandy DK, Wickman K, Williams JT (2004) Vesicular dopamine release elicits an inhibitory postsynaptic current in midbrain dopamine neurons. Neuron 42:939-946. CrossRef Medline

Bromberg-Martin ES, Matsumoto M, Hikosaka O (2010) Distinct tonic and phasic anticipatory activity in lateral habenula and dopamine neurons. Neuron 67:144-155. CrossRef Medline

Chung HJ, Ge WP, Qian X, Wiser O, Jan YN, Jan LY (2009a) G proteinactivated inwardly rectifying potassium channels mediate depotentiation of long-term potentiation. Proc Natl Acad Sci U S A 106:635-640. CrossRef Medline

Chung HJ, Qian X, Ehlers M, Jan YN, Jan LY (2009b) Neuronal activity regulates phosphorylation-dependent surface delivery of G proteinactivated inwardly rectifying potassium channels. Proc Natl Acad Sci U S A 106:629-634. CrossRef Medline

Cruz HG, Ivanova T, Lunn ML, Stoffel M, Slesinger PA, Lüscher C (2004) Bi-directional effects of GABA(B) receptor agonists on the mesolimbic dopamine system. Nat Neurosci 7:153-159. CrossRef Medline

Dascal N, Schreibmayer W, Lim NF, Wang W, Chavkin C, DiMagno L, Labarca C, Kieffer BL, Gaveriaux-Ruff C, Trollinger D (1993) Atrial G protein-activated $\mathrm{K}+$ channel: expression cloning and molecular properties. Proc Natl Acad Sci U S A 90:10235-10239. CrossRef Medline

Dutar P, Nicoll RA (1988) Pre- and postsynaptic GABAB receptors in the hippocampus have different pharmacological properties. Neuron 1:585591. CrossRef Medline

Erhardt S, Mathé JM, Chergui K, Engberg G, Svensson TH (2002) GABA(B) receptor-mediated modulation of the firing pattern of ventral tegmental area dopamine neurons in vivo. Naunyn Schmiedebergs Arch Pharmacol 365:173-180. CrossRef Medline

Gantz SC, Bunzow JR, Williams JT (2013) Spontaneous inhibitory synaptic currents mediated by a G protein-coupled receptor. Neuron 78:807-812. CrossRef Medline

Grace AA, Bunney BS (1984a) The control of firing pattern in nigral dopamine neurons: burst firing. J Neurosci 4:2877-2890. Medline

Grace AA, Bunney BS (1984b) The control of firing pattern in nigral dopamine neurons: single spike firing. J Neurosci 4:2866-2876. Medline

Grace AA, Floresco SB, Goto Y, Lodge DJ (2007) Regulation of firing of dopaminergic neurons and control of goal-directed behaviors. Trends Neurosci 30:220-227. CrossRef Medline

Guetg N, Abdel Aziz S, Holbro N, Turecek R, Rose T, Seddik R, Gassmann M, Moes S, Jenoe P, Oertner TG, Casanova E, Bettler B (2010) NMDA receptor-dependent $\mathrm{GABAB}$ receptor internalization via CaMKII phosphorylation of serine 867 in GABAB1. Proc Natl Acad Sci U S A 107: 13924-13929. CrossRef Medline

Hearing M, Kotecki L, Marron Fernandez de Velasco E, Fajardo-Serrano A, Chung HJ, Luján R, Wickman K (2013) Repeated cocaine weakens GABAB-Girk signaling in layer 5/6 pyramidal neurons in the prelimbic cortex. Neuron 80:159-170. CrossRef Medline

Hibino H, Inanobe A, Tanemoto M, Fujita A, Doi K, Kubo T, Hata Y, Takai Y, Kurachi Y (2000) Anchoring proteins confer G protein sensitivity to an inward-rectifier $\mathrm{K}(+)$ channel through the GK domain. EMBO J 19:7883. CrossRef Medline

Huang CS, Shi SH, Ule J, Ruggiu M, Barker LA, Darnell RB, Jan YN, Jan LY (2005) Common molecular pathways mediate long-term potentiation of synaptic excitation and slow synaptic inhibition. Cell 123:105-118. CrossRef Medline

Hyland BI, Reynolds JN, Hay J, Perk CG, Miller R (2002) Firing modes of midbrain dopamine cells in the freely moving rat. Neuroscience 114:475492. CrossRef Medline

Johnson SW, North RA (1992) Two types of neurone in the rat ventral tegmental area and their synaptic inputs. J Physiol 450:455-468. Medline

Kim KM, Nakajima Y, Nakajima S (1995) G protein-coupled inward rectifier modulated by dopamine agonists in cultured substantia nigra neurons. Neuroscience 69:1145-1158. CrossRef Medline

Koyrakh L, Luján R, Colón J, Karschin C, Kurachi Y, Karschin A, Wickman K (2005) Molecular and cellular diversity of neuronal G-protein-gated potassium channels. J Neurosci 25:11468-11478. CrossRef Medline

Krapivinsky G, Gordon EA, Wickman K, Velimirović B, Krapivinsky L, Clapham DE (1995) The G-protein-gated atrial K+ channel IKACh is a heteromultimer of two inwardly rectifying $\mathrm{K}(+)$-channel proteins. Nature 374:135-141. CrossRef Medline

Kubo Y, Reuveny E, Slesinger PA, Jan YN, Jan LY (1993) Primary structure and functional expression of a rat G-protein-coupled muscarinic potassium channel. Nature 364:802-806. CrossRef Medline

Kullmann DM, Moreau AW, Bakiri Y, Nicholson E (2012) Plasticity of inhibition. Neuron 75:951-962. CrossRef Medline

Labouèbe G, Lomazzi M, Cruz HG, Creton C, Luján R, Li M, Yanagawa Y, Obata K, Watanabe M, Wickman K, Boyer SB, Slesinger PA, Lüscher C (2007) RGS2 modulates coupling between GABAB receptors and GIRK channels in dopamine neurons of the ventral tegmental area. Nat Neurosci 10:1559-1568. CrossRef Medline

Lacey MG, Mercuri NB, North RA (1987) Dopamine acts on D2 receptors to increase potassium conductance in neurones of the rat substantia nigra zona compacta. J Physiol 392:397-416. Medline

Lauffer BE, Melero C, Temkin P, Lei C, Hong W, Kortemme T, von Zastrow M (2010) SNX27 mediates PDZ-directed sorting from endosomes to the plasma membrane. J Cell Biol 190:565-574. CrossRef Medline

Leonoudakis D, Conti LR, Radeke CM, McGuire LM, Vandenberg CA (2004) A multiprotein trafficking complex composed of SAP97, CASK, Veli, and Mint1 is associated with inward rectifier Kir2 potassium channels. J Biol Chem 279:19051-19063. CrossRef Medline

Lesage F, Duprat F, Fink M, Guillemare E, Coppola T, Lazdunski M, Hugnot JP (1994) Cloning provides evidence for a family of inward rectifier and G-protein coupled $\mathrm{K}+$ channels in the brain. FEBS Lett 353:37-42. CrossRef Medline

Leyland ML, Dart C. (2004) An alternatively spliced isoform of PSD-93/ Chapsyn 110 binds to the inwardly rectifying potassium channel, Kir2.1. J Biol Chem 279:43427-43436. CrossRef Medline

Lujan R, Marron Fernandez de Velasco E, Aguado C, Wickman K (2014) New insights into the therapeutic potential of Girk channels. Trends Neurosci 37:20-29. CrossRef Medline

Lunn ML, Nassirpour R, Arrabit C, Tan J, McLeod I, Arias CM, Sawchenko PE, Yates JR 3rd, Slesinger PA (2007) A unique sorting nexin regulates trafficking of potassium channels via a PDZ domain interaction. Nat Neurosci 10:1249-1259. CrossRef Medline

Lüscher C, Jan LY, Stoffel M, Malenka RC, Nicoll RA (1997) G proteincoupled inwardly rectifying $\mathrm{K}+$ channels (GIRKs) mediate postsynaptic but not presynaptic transmitter actions in hippocampal neurons. Neuron 19:687-695. CrossRef Medline

Mao J, Wang X, Chen F, Wang R, Rojas A, Shi Y, Piao H, Jiang C (2004) Molecular basis for the inhibition of $\mathrm{G}$ protein-coupled inward rectifier $\mathrm{K}(+)$ channels by protein kinase C. Proc Natl Acad Sci U S A 101:10871092. CrossRef Medline

McCutcheon JE, Conrad KL, Carr SB, Ford KA, McGehee DS, Marinelli M (2012) Dopamine neurons in the ventral tegmental area fire faster in adolescent rats than in adults. J Neurophysiol 108:1620-1630. CrossRef Medline

Nassirpour R, Bahima L, Lalive AL, Lüscher C, Luján R, Slesinger PA (2010) Morphine- and CaMKII-dependent enhancement of GIRK channel signaling in hippocampal neurons. J Neurosci 30:13419-13430. CrossRef Medline

Nehring RB, Wischmeyer E, Döring F, Veh RW, Sheng M, Karschin A (2000) 
Neuronal inwardly rectifying $\mathrm{K}(+)$ channels differentially couple to PDZ proteins of the PSD-95/SAP90 family. J Neurosci 20:156-162. Medline

Nicoll RA, Roche KW (2013) Long-term potentiation: peeling the onion. Neuropharmacology 74:18-22. CrossRef Medline

Overton P, Clark D (1992) Iontophoretically administered drugs acting at the N-methyl-D-aspartate receptor modulate burst firing in A9 dopamine neurons in the rat. Synapse 10:131-140. CrossRef Medline

Padgett CL, Lalive AL, Tan KR, Terunuma M, Munoz MB, Pangalos MN, Martínez-Hernández J, Watanabe M, Moss SJ, Luján R, Lüscher C, Slesinger PA (2012) Methamphetamine-evoked depression of GABAB receptor signaling in GABA neurons of the VTA. Neuron 73:978-989. CrossRef Medline

Pfaffinger PJ, Martin JM, Hunter DD, Nathanson NM, Hille B (1985) GTPbinding proteins couple cardiac muscarinic receptors to a $\mathrm{K}$ channel. Nature 317:536-538. CrossRef Medline

Schultz W (1998) Predictive reward signal of dopamine neurons. J Neurophysiol 80:1-27. Medline

Schultz W (2006) Behavioral theories and the neurophysiology of reward. Annu Rev Psychol 57:87-115. CrossRef Medline

Terunuma M, Vargas KJ, Wilkins ME, Ramírez OA, Jaureguiberry-Bravo M, Pangalos MN, Smart TG, Moss SJ, Couve A (2010) Prolonged activation of NMDA receptors promotes dephosphorylation and alters postendocytic sorting of GABAB receptors. Proc Natl Acad Sci U S A 107:1391813923. CrossRef Medline

Torrecilla M, Marker CL, Cintora SC, Stoffel M, Williams JT, Wickman K (2002) G-protein-gated potassium channels containing Kir3.2 and Kir3.3 subunits mediate the acute inhibitory effects of opioids on locus ceruleus neurons. J Neurosci 22:4328-4334. Medline

Turrigiano GG, Nelson SB (2000) Hebb and homeostasis in neuronal plasticity. Curr Opin Neurobiol 10:358-364. CrossRef Medline

Turrigiano GG, Leslie KR, Desai NS, Rutherford LC, Nelson SB (1998) Activity-dependent scaling of quantal amplitude in neocortical neurons. Nature 391:892-896. CrossRef Medline

Zhao S, Maxwell S, Jimenez-Beristain A, Vives J, Kuehner E, Zhao J, O’Brien C, de Felipe C, Semina E, Li M (2004) Generation of embryonic stem cells and transgenic mice expressing green fluorescence protein in midbrain dopaminergic neurons. Eur J Neurosci 19:1133-1140. CrossRef Medline

Zweifel LS, Fadok JP, Argilli E, Garelick MG, Jones GL, Dickerson TM, Allen JM, Mizumori SJ, Bonci A, Palmiter RD (2011) Activation of dopamine neurons is critical for aversive conditioning and prevention of generalized anxiety. Nat Neurosci 14:620-626. CrossRef Medline 